\title{
"FIZIČNA GEOGRAFIJA PRED NOVIMI IZZIVI", ZNANSTVENI SIMPOZIJ OB 80-LETNICI AKADEMIKA PROF. DR. IVANA GAMSA
}

Geomorfološko društvo Slovenije je v sodelovanju z Oddelkom za geografijo Filozofske fakultete, Slovensko akademijo znanosti in umetnosti, Geografskim inštitutom Antona Melika ZRC SAZU, Inštitutom za raziskovanje krasa ZRC SAZU, Zvezo geografskih društev Slovenije in drugimi ustanovami pripravilo 1. julija 2003 na Filozofski fakulteti v Ljubljani znanstveni simpozij ob 80-letnici akademika Ivana Gamsa, častnega člana Geomorfološkega društva Slovenije in Zveze geografskih društev Slovenije ter zaslužnega profesorja Univerze v Ljubljani. Glavni namen posvetovanja je bil pregled obstoječega stanja v slovenski fizični geografiji in določitev smeri nadaljnjega razvoja v skladu z obstoječimi trendi v svetovni geografiji. Prvi del srečanja je potekal v veliki dvorani SAZU, drugi del na Oddelku za geografijo Filozofske fakultete.

Na začetku sta prof. dr. Boštjan Žekš, predsednik SAZU, in prof. dr. Neva Šlibar, dekanja Filozofske fakultete, izpostavila izjemen življenjski opus akademika I. Gamsa, prof. dr. Mario Panizza $\mathrm{z}$ univerze $\mathrm{v}$ Modeni in predsednik Mednarodnega geomorfološkega združenja (IAG) pa je slavljencu izročil posebno priznanje IAG za življenjsko delo. Akademik A. Kranjc je predstavil Gamsovo delo na področju fizične geografije, s poudarkom na preučevanju krasa, s katerim se je uveljavil tudi v svetovnem merilu.

V prvem delu simpozija so sodelovali štirje ugledni fizični geografi iz tujine, dolgoletni tesni sodelavci akademika Gamsa: prof. dr. Mario Panizza z univerze v Modeni (Italija), upokojeni prof. dr. Jean Nicod z univerze Aix-en-Provence-Marseille (Francija), prof. dr. Ugo Sauro z univerze v Padovi (Italija) in akademik prof. dr. Andrija Bognar z univerze v Zagrebu (Hrvaška). Naši gostje so predstavili svoje poglede na nekatera področja fizične geografije, pri čemer so deloma izhajali tudi iz delovanja akademika I. Gamsa. M. Panizza je prikazal italijanske izkušnje pri preučevanju geomorfološke naravne dediščne z vidika kvantifikacije njihove 'vrednosti', J. Nicod pa Gamsov prispevek k delu študijske skupine Človek in kras v okviru Mednarodne geografske unije. U. Sauro je govoril o vrtačah kot primeru izjemne zapletenosti geomorfnih procesov ter izpostavil ključni pomen Gamsovih preučevanj podtalne in pospešene korozije za razumevanje nastajanja vrtač, A. Bognar pa je predstavil velik pomen Gamsove pobude za detajlno geomorfološko kartiranje v nekdanji Jugoslaviji, ki je oživila hrvaško geomorfologijo in jo pomagala usmeriti v aplikativna preučevanja. Prvi del posvetovanja se je zaključil z Gamsovim prispevkom o novih izzivih fizične geografije, v katerem je izpostavil nujnost preučevanja medsebojne povezanosti pokrajinotvornih dejavnikov, uporabo eksaktnih metod in usmeritev fizične geografije $\mathrm{v}$ aktualne teme, ki so $v$ ospredju tudi v svetovni geografiji.

V drugem delu posvetovanja je prispevke o novih izzivih fizične geografije predstavilo sedem domačih strokovnjakov, večinoma bivši študentje profesorja Gamsa. Glavni namen je bil prikaz obstoječega stanja na ključnih segmentih fizične geografije, s posebnim poudarkom na iskanju smeri nadaljnjega razvoja. Prispevki z znanstvenega simpozija in bibliografija akademika I. Gamsa so bili objavljeni v 20. številki publikacije Dela.

Karel Natek 